\title{
Women on Corporate Boards and Firm Performance, Preliminary Results from Italian Listed Companies after the Introduction of Gender Quota Law 120/2011
}

\section{Shabbir MS*}

International Islamic University, Islamabad, Pakistan

\begin{abstract}
The relationship between the presence of women on corporate board and firm performance has attracted a growing research interest in corporate governance literature. In this study we analyse this topic in Italy, a country that has recently introduced the gender quota law 120/2011. We investigate this topic using regression analysis on a sample of 705 Italian listed companies after the introduction of the gender quota law. Our findings highlight that the presence of women on corporate board does not influence firm performance. Many explanations and managerial implications may be deduced from these results, as shown in the paper.
\end{abstract}

Keywords: Gender Diversity; Women; Firm performance; Law 120/2011; Italy

\section{Introduction}

The composition of corporate boards is a topic of vital importance within corporate governance studies, especially in global market and in a situation of global financial crisis [1-5]. Corporate boards typically perform two roles [6,7]: a monitoring role (agency theory) and an advisory role to management (resource dependence theory). Corporate governance literature suggests that the board composition affects the way the board performs these roles. Recently, board diversity (in terms of gender or ethnic background, education, proportion of foreigners) has gained considerable interest in corporate governance literature $[8,9]$. The main question is whether board diversity enhance board's capacity and competencies, and, consequently, firm performance. Several arguments have been formulated to demonstrate the importance of diversity on corporate boards both in the light of agency theory and in the resource dependence framework.

Board diversity is a stronger monitor of behavior, as board members with a different gender, ethnicity or cultural background bring different viewpoints to board oversight and impose different kind of questions which would not have been asked within a non-diversified board and, therefore, impose a broader view [10-13]. In other words, a higher degree of diversity may benefit the board's decision process as new perspectives on various issues are represented combined with a mutual exchange of ideas stemming from board members with dispersed backgrounds and life experience [14]. Moreover, board diversity may also serve as a positive signal to the firm's stakeholders such as consumers, suppliers and the community improving its reputation. Specifically, women, being generally excluded from the old boys' club, can enhance a board's independence of thought and monitoring functions $[10,15]$.

The advisory role could be enhanced by a greater female presence, as their different professional backgrounds, capacities, competencies, and problem-solving skills provide ownership and top managers with valuable advice $[16,17]$. Diversity increases creativity and innovation, creates more effective problem-solving; corporate leadership is enhanced more effectively when diversity increases within the firm. Specifically, increased board diversity may facilitate an enhanced competence profile for the board as a whole, since it avoids that a number of qualified board candidates not normally considered when searching for new members are excluded. In fact, a higher degree of diversity in a corporation's board may serve as a positive signal to potential job applications, thereby attracting well qualified persons outside the old's boy circle where board candidates are usually recruit from. At the same time, board diversity may increase the competition within the firm's internal labor market since women know that they are not excluded from the highest positions in the firm. Finally, resource dependence theory also argues that boards serve to link the company to other external organizations in order to address environmental dependencies [18]. Several studies suggested that the current volatile and uncertain market environment increase the demand for corporate board diversity to solve complex issues [19]. Women and minorities have different experiences on aspects like the workplace, marketplace, public services and community, so that debates and decisions will be considered from a broader view. Hillman et al. [19] found, for example, that female board members are able to provide non-business backgrounds, hold advanced degrees (like an MBA), and join many boards at a faster rate than their male counterparts. Robinson and Dechant [20] and Zelechowski and Bilimoria [21] suggest that more diversity in the corporation influences the understanding of the marketplace, since the market in which corporations operate are becoming more diverse. Finally, diversity will generate successful global relationships since cultural sensitivity is critical when a firm operates in a global environment.

Based on these considerations, many studies have sought to explore whether board diversity, especially in relation to gender, may facilitate the board with an enhanced competence profile, which could stimulate firm performance $[10,12]$. In synthesis, the presence of female board members may enhance firm performance if women bring an additional perception to board decision-making. On the other hand, female board

*Corresponding author: Shabbir MS, International Islamic University, Islamabad, Pakistan, Tel: 0343-6656850; E-mail: mshahzad786.pk11@gmail.com

Received April 17, 2017; Accepted January 29, 2018; Published February 04 2018

Citation: Shabbir MS (2018) Women on Corporate Boards and Firm Performance, Preliminary Results from Italian Listed Companies after the Introduction of Gender Quota Law 120/2011. J Bus Fin Aff 7: 316. doi: 10.4172/2167-0234.1000316

Copyright: (c) 2018 Shabbir MS. This is an open-access article distributed under the terms of the Creative Commons Attribution License, which permits unrestricted use, distribution, and reproduction in any medium, provided the original author and source are credited. 
members may have a negative effect if the decision to appoint women is made because of societal pressure for greater equality of the sexes [22].

The gender issue is now also subject of a policy debate, which is leading a number of European countries to introduce some kind of compulsory. In fact, women still hold very few corporate seats, even if companies are convinced of the value of gender diversity [23]. In Europe, female representation on board rooms is too disappointing. In 2013, women were still underweight in corporate boards and were barely present in executive committees [24], even if there is increasing pressure to have female presence on board, due both to more attention on reducing the gender gap and to analyze the influence of women on firm performance, suggesting that diverse boards are, under certain circumstances, more effective.

The Italian boards of directors are characterized by a very limited participation of women. In addition, in Italy board candidates are extremely rarely recruited from official job market. Instead, they are usually recruited from a small group of business people who are closely connected with each other. Therefore, one may speak of the existence of the old boy's network in which the members share similar social values and norms $[10,12]$. As a consequence, in order to get elected to the board, one might influence the existing members of the old boy's network convincing them that he/she is sharing the same norms as members in the network.

This situation has persisted until 2011, when the Law 120/2011 (socalled "Legge Golfo-Mosca") has mandated gender quotas for Italianlisted companies. This provision has been in force since August 2012 and is subject to a three-board-terms sunset clause. According to the new law, at least one-third (one-fifth for the first term) of board seats must be held by female directors. Thus, the introduction of this law makes interesting to study if women have a significant and positive impact on Italian-listed companies performance. Clearly, it is an open question whether differences between the genders have a significant and positive influence on firm performance, but there is no doubt that this issue needs to be further explored in the corporate governance literature. Thus, the aim of this paper is to shed some light on the influence of female representation on Italian corporate board on firm performance.

\section{Hypothesis}

H1: A higher degree of women represented in corporate boards have a positive and significant impact on firm performance.

Our research contributes to the corporate governance literature in three ways. Firstly, analyzing the effect that the women representation on the board has on firm performance, we shed new light on an under-researched key variable in corporate governance literature in order to understand the causality between the board diversity and firm performance. Secondly, our research also contributes to the agency theory and the resource dependence theory. Finally, studies on the relationship between female board representation and firm performance are mainly focused on US or Danish companies. Analyzing all the Italian listed companies, we try to give new evidence to this topic and to extend the corporate governance literature on board diversity.

The paper is organized as follows. Section 2 presents a brief literature review on women representation on board rooms and firm performance. Section 3 describes data, variables and methodology, whilst in section 4 results are discussed. Finally (section 5), conclusions, limitations and main managerial implication follow.

\section{Literature Review}

In fact, while some authors find a positive relationship between gender diversity and Tobin's $Q$, or accounting measures of performance $[25,26]$, others do not identify statistically significant results. Burton and Ryall [27] find that firms with gender diversity are less likely to succumb to corporate failure. Daily et al. [28] examine the extent whether there has been an increase in women's representation on corporate boards and CEO positions from 1987 to 1996 in the US. They document that the number of female inside directors is astonishingly small, only 0.006 per cent.

Athey et al. [29], state that the female underrepresentation on top executive roles may be due to discrimination by male directors. Another study suggests that women and men have different attitudes on various policy issues. For instance, Alvarez and McCaffery [14] conduct an empirical study exploring the gender gap between attitudes on potential uses of the budget surplus and gender. They find a significant gender gap with men being far more likely than women to support tax cuts or paying down national debt, i.e., women are far more likely than men to not express an opinion or to confess ignorance about fiscal matters. Farrel and Hersch [30], using a large sample from 1990 to 1999, estimate what determines the likelihood that a woman is added to the board of directors. They find that the probability of adding a woman to a board in a given year is negatively related to the number of female directors already on the board. Singh et al. [31,32] conduct a large survey of women directors on top UK boards. They show that even though female representation has increased over the years, the proportion of firms that had at least one female director has dropped by July 2000 from $64 \%$ in 1999 to $58 \%$. They also argue that there is a need for a better understanding of how women directors contribute to board's performance, emphasising that the theory linking board diversity to firm performance is not well developed. Carter et al. [25] examine how the proportion of women and different ethnic origin influence firm performance measured by Tobin's Q. Based on data from Fortune 1000, they find that firms with at least two female directors have a better performance.

Erhardt et al. [26] also conduct a study based on US data and find that a higher degree of board diversity is associated with superior performance. Adams and Ferreira [15] study the impact of board diversity on managerial incentives. They find a significant association between the proportion of woman and the stock market volatility, i.e., firms with boards that have a lower fraction of woman tend to have a more volatile stock price. Using a sample of listed Danish firms during the period 1998-2001, Rose [12] studies the impact of female board representation on firm performance. She does not find any significant relationship between female board representation and firm performance as measured by Tobin's Q. Erkut et al. [33] perform a qualitative study on a few Fortune 1000 companies and find that the point in which women influence board decisions is when the board contains at least three women.

Tarr-Whelan [34] presents several reasons for why firms should strive to include more women in senior positions. She claims that firms with higher fraction of women in senior positions have higher profits, and a greater ability to survive financial downturns. Further, she argues for a phenomenon called the $30 \%$ solution: it has been proven that if women represent at least one-third of a group they are able to influence decisions. Women's ideas are, in fact, more likely to resonate if they are supported and amplified by other women. Adams and Ferreira [15] find a negative relationship between gender diversity and both Tobin's $Q$ and return on assets. However, in companies with weaker shareholder 
Citation: Shabbir MS (2018) Women on Corporate Boards and Firm Performance, Preliminary Results from Italian Listed Companies after the Introduction of Gender Quota Law 120/2011. J Bus Fin Aff 7: 316. doi: 10.4172/2167-0234.1000316

Page 3 of 6

protection, gender diversity positively affects performance, while in well-governed companies additional monitoring (i.e., that exerted by diverse boards) has a negative impact.

According to Anderson et al. [35] the impact of diversity on firm performance varies with company characteristics. Board diversity positively affects the performance of more complex companies, but has detrimental effects in less complex organizations. Dobbin and Jung [36] study the relation between female directors and US firm performance. They find evidence of a negative correlation between gender board diversity and Tobin's $\mathrm{Q}$, but no significative relation between gender diversity and ROA. Erhardt et al. [26] look at 112 leading US firms and find a positive correlation between ROA and diversity on boards. Ahern and Dittmar suggest a negative impact on the value of companies with all-male boards, while a positive market reaction is found for those that have at least one female director.

\section{Data and Methodology}

\section{Sample}

Our sample consists of Italian companies listed on the Milan Stock Exchange during 2012-2014. The sample we start with consists of an unbalanced panel of 705 companies-level observations during the three-year period. The number of companies is 235, 230, 240 in 2012, 2013 and 2014, respectively, while the number of unique company is 271 in the sample overall. Banks, insurance companies and football clubs are excluded due to the difficulty of calculating Tobin's $Q$ for these firms [12]. Data on financial performance as well as on board composition are gathered from CONSOB and AIDA databases, which are the most comprehensive database covering all companies in Italy. Data about individual board member (i.e., gender, independence, payment, education) are directly hand-collected from individual companies' corporate governance reports and firm's annual account for the years 2012-2014.

\section{Variables}

Table 1 describes the variables used in the analysis, whilst Table 2 shows summary descriptive statistics from the sample.

Tobin's $Q$ is used as dependent variable to measure firm performance. The average Tobin's $\mathrm{Q}$ in our study is 1.39 with a relatively low standard deviation of 1.09 . Tobin's $\mathrm{Q}$ is a widely applied measure within the corporate governance literature serving as a proxy for a firm's ability to generate shareholder wealth [12]. According to Himmelberg et al. [37] and Rose [12], if the ratio is less than 1 the firm is cheaper to buy capacity in the financial markets than in the real asset markets. If the ratio is high than 1 , it reflects the presence of strong comparative advantage or growth opportunities. It is possible to use other metrics such as return on equity (ROE) to measure the firm performance. However, we decide to use Tobin's Q because it is less sensitive to management's choice of asset valuation principles.

Table 2 shows that in $90 \%$ of the companies there is at least one woman on the board. This value is certainly due to the introduction of the law 120/2011. In fact, previous studies [10] analyzing the female representation on board before the introduction of the gender quota law show that there is at least one woman on the board in only $22 \%$

\begin{tabular}{|l|l|}
\hline Variables & Description \\
\hline Tobin's Q & The market value of equity plus book value of debt all divided with book value of assets \\
\hline Women & The proportion of persons on the supervisory board who are women \\
\hline Independent & Dummy variable equal to one if at least one woman holds a board seat, 0 otherwise \\
\hline Ownership & S of independent directors on the board \\
\hline Economists & Number of directors on the board who are economists \\
\hline Lawyers & Number of directors on the board who are lawyers \\
\hline Engineers & Number of directors on the board who are engineers \\
\hline Payment & Average payment for each person on the board \\
\hline Growth & The increase in book assets over the period $2012-2014$ \\
\hline Ln Firm Size & Natural logarithm of firms' turnover (2014) \\
\hline SD Size & Standard deviation of turnover serving as a simple proxy for firm's risk \\
\hline Manufacturing & Dummy variable, which equal one if a company is in the manufacturing industry, 0 otherwise \\
\hline Service and Trade & Dummy variable, which equal one if a company is in the service and trade industry, 0 otherwise \\
\hline IT/Tlc & Dummy variable, which equal one if a company is in the IT/Telecommunication industry, 0 otherwise \\
\hline
\end{tabular}

Table 1: Variables.

\begin{tabular}{|c|c|c|c|c|}
\hline & Minimum & Maximum & Mean & Std Dev \\
\hline Tobin's Q & 1.81 & 7.57 & 1.39 & 1.09 \\
\hline Women & 0.00 & 0.64 & 0.21 & 0.062 \\
\hline D-Women & 0 & 1 & 0.90 & 0.031 \\
\hline Independent & 0 & 1 & 0.24 & 0.36 \\
\hline Ownership & 20 & 100 & 58.01 & 13.14 \\
\hline Economists & 0 & 1 & 0.32 & 0.291 \\
\hline Lawyers & 0 & 0.45 & 0.26 & 0.263 \\
\hline Engineers & 0 & 0.85 & 0.18 & 0.168 \\
\hline Payment & 0.00 & 0.98 & 57.06 & 5.18 \\
\hline Growth & -1.43 & 1.00 & 0.34 & 0.54 \\
\hline Ln Firm Size & 1.839 & 10.31971 & 6.775 & 1.662 \\
\hline SD Size & 0 & 10163.09 & 801.687 & 1989.71 \\
\hline
\end{tabular}

Table 2: Descriptive statistics from the sample. 
Citation: Shabbir MS (2018) Women on Corporate Boards and Firm Performance, Preliminary Results from Italian Listed Companies after the Introduction of Gender Quota Law 120/2011. J Bus Fin Aff 7: 316. doi: 10.4172/2167-0234.1000316

Page 4 of 6

of the cases. However, despite the introduction of the law, women representation is very low as they represent on average only $21 \%$ of all boards. This result is far below that of Scandinavia (about $40 \%$ ), but it is less distant from others continental European countries according to European Commission [24]. This is an interesting but not surprising result, since in Italy the occupation of companies' board seats is still almost entirely restricted to men. We also include a number of control variables regarding board characteristics (ownership, independent, level of education, payment), growth, size, and industry dummies.

With regards to board characteristics, Table 2 confirms the traditional features of the corporate governance structure of the Italian companies. Firstly, the ownership concentration is relatively high, since the average concentrated ownership is $58 \%$. Reviewing corporate governance literature, concentrated ownership is considered a tool to reduce agency costs [38]. For this reason we include this variable in the analysis. Secondly, statistics also show a low presence of independent directors (less than one-third of the board). In the resource dependence framework, independent directors are considered a key variable to provide managers with valuable advice, which is why independent directors is included in our study. Having a degree in economics represents the most common educational background for a board member (32\%), followed by lawyers (26\%) and engineers (18\%).

The average payment for each member is about 57,000 euro on annual basis. According to Rose [12], this variable should have a positive impact on firm performance as the incentive for management to increase firm value is enhanced if payment is increased. Growth is used as control variable because it seems plausible that firms that experience growth should also expect to have higher Tobin's Q. Regarding firm size, it seems plausible that agency costs are more substantial in larger firms with larger board due to the free rider problems associated with these firms [12]. The model also includes industry dummies.

Finally, we analyze director characteristics in order to highlight differences between female and male directors. Significant differences emerge with respect to ownership and independence. Women are owner in one case out of ten (less frequently than men), while only a minority of them are independent directors (nearly $18 \%$ of woman are classified independent directors, whereas $42 \%$ of men); hence, in almost half of the cases, women are neither owner nor independent directors. No significant difference emerges, instead, with respect to education and payment. First, women and man appear to hold a bachelor's degree with the same frequency ( $85 \%$ for both). In particular, having a degree in economics is the most common educational background for both women (51\%) and man (53\%), whilst women hold a bachelor's degree in law with a higher frequency than men ( $43 \%$ vs. $30 \%)$. Female and male board members having a background in engineering represent $16 \%$ and $17 \%$, respectively. Second, no significant differences emerge with respect to average payment for women and men on an annual basis.

\section{Results}

Tables 3 and 4 show the results of our cross-sectional OLS regression where the observations from each year are staged. Table 3 shows the result when the dependent variable is regressed against the proportion of women, whilst Table 4 shows the results when Tobin's Q is regressed against the variable $\mathrm{D}$ Women.

Results in Table 3 show that when Tobin's Q is regressed against the proportion of women the coefficient is positive, but insignificantly different from zero. The only control variables that are significantly

\begin{tabular}{|c|c|c|c|c|}
\hline Variables & Coefficient & Standard Error & T Value & P Value \\
\hline Intercept & 1.614 & 2.837 & 0.54 & 0.617 \\
\hline Women & 0.052 & 0.319 & 0.18 & 0.781 \\
\hline Independent & 0.702 & 0.237 & 2.96 & 0.362 \\
\hline Ownership & -0.004 & 0.018 & -0.31 & 0.767 \\
\hline Economists & 0.177 & 0.227 & 0.78 & 0.499 \\
\hline Lawyers & 1.336 & 0.117 & 1.35 & 0.520 \\
\hline Engineers & 0.204 & 0.632 & 0.31 & 0.731 \\
\hline Payment & 1.051 & 0.863 & 1.22 & 0.232 \\
\hline Growth & 0.695 & 0.261 & 2.83 & 0.003 \\
\hline Ln firm Size & -0.124 & 0.078 & -1.33 & 0.188 \\
\hline SD Size & 0.000 & 0.000 & 0.77 & 0.479 \\
\hline Manufacturing & 0.096 & 0.468 & 0.19 & 0.656 \\
\hline $\begin{array}{c}\text { Service and } \\
\text { Trade }\end{array}$ & 0.592 & 0.341 & 2.49 & 0.612 \\
\hline IT/Tlc & 0.639 & 0.322 & 2.86 & 0.002 \\
\hline
\end{tabular}

Table 3: Results of the regression analysis when Tobin's $Q$ is regressed against Women.

\begin{tabular}{|c|c|c|c|c|}
\hline Variables & Coefficient & Standard Error & t-Value & P Value \\
\hline Intercept & 1.394 & 2.787 & 0.54 & 0.589 \\
\hline D Women & 0.284 & 1.039 & 0.28 & 0.769 \\
\hline Independent & 0.078 & 0.959 & 0.09 & 0.965 \\
\hline Ownership & -0.005 & 0.020 & -0.29 & 0.733 \\
\hline Economists & 0.179 & 0.231 & 0.81 & 0.462 \\
\hline Lawyers & 1.369 & 0.115 & 1.93 & 0.587 \\
\hline Engineers & 0.238 & 0.656 & 0.33 & 0.784 \\
\hline Payment & 1.049 & 0.887 & 1.19 & 0.240 \\
\hline Growth & 0.683 & 0.266 & 2.83 & 0.003 \\
\hline Ln Firm Size & -0.116 & 0.084 & -1.42 & 0.162 \\
\hline SD Size & 0.000 & 0.000 & 0.75 & 0.469 \\
\hline Manufacturing & 0.085 & 0.490 & 0.20 & 0.677 \\
\hline Service and & 0.505 & 0.372 & 2.51 & 0.638 \\
\hline Trade & & & & 0.002 \\
\hline IT/Tlc & 0.683 & 0.319 & 2.79 & 0.96 \\
\hline
\end{tabular}

Table 4: Results of the regression analysis when Tobin's $Q$ is regressed against D-Women.

different from zero are growth and IT/TlC. While $\mathrm{R}^{2}$ explains $78 \%$ of the model and the $F$ value is 2.05 . However, F-test shows that whole model is statistically insignificant.

The same results are reflected in Table 4 where the main independent variable is $\mathrm{D}$ Women. Also in this case the coefficient is positive but insignificant; hence, our results show that the gender has insignificant impact on firm performance in Italian companies. Whereas, $\mathrm{R}^{2}$ explains $81 \%$ of the model and the $F$ value is 2.06 . The below test values show that our whole model for $\mathrm{D}$ women is also statistically insignificant. Also when Tobin's $Q$ is regressed against board member's educational background, the coefficient is positive but insignificantly different from zero. Therefore, also member's educational background does not impact performance.

\section{Conclusion and Recommendation}

The purpose of this paper is to provide empirical evidence on one of the more significant topic in the recent corporate governance literature, i.e., the impact of female representation on the board on firm performance.

Understanding the influence of gender diversity on firm financial performance has, in fact, important implications for managers, shareholders, stakeholders, and policy makers. Until the introduction of 
Citation: Shabbir MS (2018) Women on Corporate Boards and Firm Performance, Preliminary Results from Italian Listed Companies after the Introduction of Gender Quota Law 120/2011. J Bus Fin Aff 7: 316. doi: 10.4172/2167-0234.1000316

Page 5 of 6

a gender quota law in 2011, women's representation on Italian corporate boards was the concern of minority of companies. When women were present in most cases they were alone and their appointment was mainly driven by family representation on the board rather than by a selection based on merit [10]. Hence, the appointment of familyaffiliated woman may have been responsible for poorer outcomes in terms of firm performance. The introduction of law 120/2011 would have to change this scenario. In fact, if women will be selected based on merit and professional background, we might expect to see some positive results, otherwise if companies will appoint women only because the law demands it, we might expect to see negative results.

Our research has provided Italian evidence showing that gender diversity does not influence firm performance, hence $\mathrm{H} 1$ must be rejected. Several reasons may explain these results. First, in Italy nearly two-third of the companies are family-controlled. Thus, companies appoint women in the board or for family reasons or just for respecting the law. Hence, women are relegated in a secondary role without any impact on firm performance. Second, board members not originating from the traditional "old boys club" may have decided to interiorize the traditional circles, suppressing any special feature stemming from the board members' unconventional background [12]. In other words, there might be a process of silent learning where the unconventional board members have learned and interiorized the norms and values of the conventional board members. This could be the only way to be noted by the CEO for a career in the firm, including appointment to the firms' board rooms. As a consequence, the gains from having female board members are never realized or reflected in any chosen performance measure. Even though the hypothesis of our study is not confirmed, it is, however, possible to argue that exist several reasons why boards of directors should be more diversified and are more similar to the rest of society beyond the simple legislation. Thus, a policy implication from our results is that more research is needed in order to understand whether board members seek to suppress their unconventional attributes [12].

Our study has also some limitations. Firstly, our data were collected exclusively in Italy. Hence, our results have to be interpreted in the light of the particular context in which Italian companies operate. Further studies should investigate if the impact of women representation on firm performance varies across countries. Other countries have different laws, cultural environments, historical backgrounds, and other factors that might affect board diversity. This would result in a more thorough understanding of whether women board directors influence board decisions and how. Secondly, in our study we use only the ratio of women directors as an indicator of board diversity. Further research may use other gender diversity indices such as the Blau and Shannon indices. Finally, our research is carried out on a short span of time. Future research should analyze the effect of the new legislation after the here-board terms sunset clause. Moreover, due to the short span of our study, we do not address the endogeneity issues that arise because of firm characteristics difficult to observe, which could affect the appointment of female directors [10]. Thus, further studies could include a viable instrument to control for the endogeneity problem.

\section{References}

1. Abatecola G, Farina V, Gordini N (2013) Boards of directors in troubled waters: Enhancing the survival chances of distressed firms. In: Carretta A, Mattarocci G editors. Financial System in Troubled Waters: Information, Strategies, and Governance to Enhance Performance in Risky Times, Routledge, London.

2. Abatecola G, Farina V, Gordini N (2014) Board effectiveness in corporate crises: Lessons from the evolving empirical research. The International Journal of Business in Society 14: 531-542.
3. Gordini N (2010) Market-Driven Management: A Critical Literature Review. Symphonya, Emerging Issues in Management, pp: 95-107.

4. Gordini N (2012) The Impact of Outsiders on Small Family Firm Performance: Evidence from Italy. World Journal of Management 4: 14-35.

5. Gordini N (2016) Does the Family Status of the CFO Matter to Enhance Family Firm Performance? Evidence from a Sample of Small and Medium-Sized Italian Family Firms. International Journal of Entrepreneurship and Small Business 28: 36-57.

6. Fama EF, Jensen MC (1983) Separation of ownership and control. Journal of Law and Economics 26: 301-325

7. Hermalin BE, Weisbach MS (2003) Boards of directors as an endogenously determined institution: a survey of the economic literature. Economy policy review 4: 456-478.

8. Masulis RW, Wang C, Xie F (2012) Globalizing the boardroom -The Effects of Foreign Directors on Corporate Governance and Firm Performance. Journal of Accounting and Economics 53: 527-554.

9. Post C, Byron K (2015) Women on Boards and Firm Financial Performance: A Meta-Analysis. Academy of Management Journal 58: 1546-1571.

10. Bianco M, Ciavarella A, Signoretti R (2015) Women in corporate boards in Italy: the role of family connections. Corporate Governance an International Review 23: 1-16.

11. Adams R, Funk P (2012) Beyond the glass ceiling: does gender matter? Management Science 58: 219-235.

12. Rose C (2007) Does female board representation influence firm performance? The Danish evidence. Corporate Governance: An International Review 15: 404-413.

13. Carter DA, D'Souza F Simkins BJ, Simpson WG (2010) The Gender and Ethnic Diversity of US Boards and Board Committees and Firm Financia Performance. Corporate Governance: An International Review 18: 396-414.

14. Alvarez RM, McCaffery EG (2000) Gender and American Politics: Women, Men and the Political Process. Political Science Quarterly 91: 93-110.

15. Adams RB, Ferreira D (2009) Women in the boardroom and their impact on governance and performance. Journal of Financial Economics 94: 291-309.

16. Anderson R, Baker KH (2010) Corporate governance: A synthesis of theory, research, and practice. John Wiley \& Sons, pp: 225-242.

17. Terjesen S, Sealy R, Singh V (2009) Women Directors on Corporate Boards: A Review and Research Agenda. Corporate Governance: An International Review 17: 320-337

18. Pfeffer J, Salancik GR (1978) The external control of organizations. Harper and Row, New York.

19. Hillman AJ, Cannella AA, Harris IC (2002) Women and racial minorities in the boardroom: How do directors differ? Journal of Management 28: 747-763.

20. Robinson G, Dechant K (1997) Building a business case for diversity. Academy of Management Executive 11: 21-31.

21. Zelechowski D, Bilimoria D (2004) Characteristics of women and men corporate inside directors in the US. Corporate Governance: An International Review 12 337-342.

22. Kenneth AR, Dittmar AK (2009) The changing of the boards: The impact on firm valuation of mandated female board representation. The Quarterly Journal of Economics 127: 137-197.

23. Terjesen S, Singh V (2008) Female presence on Corporate Boards: A multicountry study of Environmental context. Journal of Business Ethics 83: 55-63.

24. European Commission (2013) Gender equality in the Member States. Brussels European Commission.

25. Carter DA, Simkins BJ, Simpson WG (2003) Corporate Governance, Board Diversity and Firm Value. The Financial Review 38: 33-35.

26. Erhardt N, Werbel JD, Shrader CB (2003) Board of director diversity and firm financial performance. Corporate Governance: An International Review 1: 102 111.

27. Burton C, Ryall C (1995) Enterprising Nation: Renewing Australia's Managers to Meet the Challenges of the Asia-Pacific Century. Industry Task Force on Leadership and Management Skills. 
Citation: Shabbir MS (2018) Women on Corporate Boards and Firm Performance, Preliminary Results from Italian Listed Companies after the Introduction of Gender Quota Law 120/2011. J Bus Fin Aff 7: 316. doi: 10.4172/2167-0234.1000316

Page 6 of 6

28. Daily CM, Certo ST, Dalton RS (1999) A decade of corporate women: some progress in the boardroom, none in the executive suite. Strategic Management Journal 90: 93-99.

29. Athey S, Avery C, Zemsky P (2000) Mentoring and Diversity. American Economic Review 90: 765-786.

30. Farrell KA, Hersch PL (2005) Additions to corporate boards: The effect of gender. Journal of Corporate Finance 11: 85-206.

31. Singh V, Vinnicombe S, Johnson P (2001) Women Directors on Top UK Boards. Corporate Governance: An International Review 9: 206-216.

32. Singh V, Terjesen S, Vinnicombe S (2008) Newly appointed directors in the boardroom: how do women and men differ? European Management Journal 26: 48-58.

33. Erkut S, Kramer VW, Konrad AM (2008) Critical mass: Does the number of women on a corporate board make a difference?
34. Tarr-Whelan L (2009) Women lead the way. Berrett-Koehler Publishers, New York.

35. Anderson RC, Reeb DM, Upadhyay A, Zhao W (2011) The economics of director heterogeneity. Financial Management 40: 5-38.

36. Dobbin F, Jung J (2011) Corporate Board Gender Diversity and Stock Performance: The Competence Gap or Institutional Investor Bias? North Carolina Law Review 89: 809-838.

37. Himmelberg CP, Hubbard RG, and Palia D (1999) Understanding the determinants of managerial ownership and the link between ownership and performance. Journal of Financial Economics 53: 353-384.

38. Shleifer A, Vishny RW (1997) A survey of corporate governance. Journal of Finance 52: 759-783. 